\title{
NARRATIIVINEN NÄKÖKULMA OPETTAJUUTEEN
}

HEIKKINEN, H. L. T. \& SYRJÄLÄ, L. (toim.). Minussa elää monta tarinaa. Kirjoituksia opettajuudesta. Kansanvalistusseura 2002.

Kirjan lukeminen voi olla ajatuksia herättävä matka ja matkasta voi kirjoittaa tarinan. Kirjoitukseni onkin tarina lukumatkasta opettajuuteen.

Kirjallisuuden tutkimuksen alueella tapahtumat palautetaan ajalliseen järjestykseensä tarinaa käyttäen. Narratiivisen tutkimuksessa analyysin pyrkimys on samankaltainen. Hannu L. T. Heikkisen mukaan narratiivisessa analyysissa mielenkiinto suuntautuu ehjän ja juonellisen, ajassa etenevän tarinan tuottamiseen, mikä innostaa kokeilevaan kirjoittamiseen. Tuntuu siis luontevalta tässäkin yhteydessä luoda tarina tarinoiden synnyttämistä pohdinnoista.

Otsikon Minussa elää monta tarinaa voi ajatella ilmentävän sekä kirjan sisältöä että narratiivisuuteen liittyvää identiteetin käsitettä. Kirja sisältää kaksitoista erillistä tarinaa, joista osa nimetään opettajakuviksi ja osa narratiivien sovelluksien esittelyksi. Identiteetin käsitteeseen otsikko voisi viitata siinä, että narratiivisuudessa identiteetin katsotaan rakentuvan aina uudelleen tilanteesta toiseen.

Lukumatkan aluksi tutustun kirjan rakenteeseen. Lyhyttä johdantoa seuraavat tutkijoiden tuottamat tarinat, jotka perustuvat eri tavoin hankittuihin opettajien elämänkertoihin. Narratiivisuuden teoreettisia ja filosofisia perustoja käsittelevä osuus on sijoitettu teoksen loppuun, joten lukija pääsee tarinoiden maailmaan heti kirjan alusta. Ratkaisu on hyvä ja suosii eläytyvää lukutapaa. Pikalukuna tapahtuva matkan ensimmäinen kierros on lukuelämys. Opettajuudesta voi kirjoittaa näinkin. Kirjan opettajuutta normittamaton henki saa aikaan tuoreuden tunnun. Opettajaideaalien määrittelyn ja opetuksellisten ohjeitten sijaan kuunnellaan opettajien kertomaa.

Toisen lukukierroksen tavoitteena on paneutua tarkemmin sekä itse tarinoihin että narratiivisuutta käsittelevään osuuteen. Opettajakuvissa kuvataan opettajien elämäkertaaineistoa. Saara-Leena Syrjälän kirjoitus Kansankynttilä kertoo kaikkitietävän kansankynttilän tyyppitarinan, jonka on tarkoitus olla esimerkki narratiivisesta analyysista. Opettajien elämäntarinoiden suorista lainauksista syntyy yksi tarina, joka tuo esiin opettajiin perinteisesti yhdistettyjä ominaisuuksia tai asioita: synnynnäinen opettaja, opettajaleikit lapsuudessa, halu parantaa maailmaa, rakkaus isänmaahan, kylän vaikuttaja, työn ajattelu vapaa-aikana, arvioinnin vaikeus ja kutsumustyö. Kansakynttilän tarina on osuva, mutta sitä seuraava opettajaideaalien ja kapinoivien tarinoiden pohdinta jää ohueksi. Esitetyt kapinoinnin muodot eivät onnistu murtamaan mallitarinoiden mahtia. Uudenlaisen ajattelun ja opettajuuden löytyminen on prosessi, jossa arvot on mietittävä uudelleen sekä yksilön että yhteiskunnan tasolla.

Tarina Koulu alkaa on muistoja herättävä lukukokemus.
Opiskelijana seminaarissa tarinassa Kaisa-Marian osuus tuo nostalgisesti mieleen mustavalkoiset Suomi-elokuvat. Artikkeli Polkuja yliopistossa lähestyy opettajankoulutusaikaa analyyttisemmin. Tekstissä vertaillaan Kaislan ja Liisan tarinoita, ja opettajaksi kasvamisen kehystä rakennetaan lapsuuden kokemuksista lähtien. Opettajankoulutuksen rakennetta ja toimintatapoja käsiteltäessä tuodaan esiin opiskelun kiireinen tahti sekä opiskelijoiden välinen kilpailu. Analysoidut elämäntarinat viittaavat kirjoittajien mukaan opettajankoulutuksessa vallinneeseen piiloopetussuunnitelmaan.

Raija Erkkilä ja Maarit Mäkelä pohtivat artikkelissaan sitä, tapahtuuko opettajaksi kasvaminen suorittamisen vai ymmärtämisen kautta. He kirjoittavat: "Jos oletetaan, että identiteetti rakentuu sosiaalisten prosessien kautta, silloin ihmistä ympäröivä yhteiskunta, kulttuuri ja elämäntapa vaikuttavat merkittävästi identiteetin muodostumiseen." Erkkilän ja Mäkelän mielestä tämä merkitsee sitä, että opiskelijan aikaisempien elämänvaiheiden tunteminen voi auttaa opettajankouluttajia ymmärtämään opiskelijan opiskeluprosessia. Elämänvaiheiden tuntemus auttaisi myös ymmärtämään, miksi opiskelijat kehittyvät erilaisiksi opettajiksi. On varmasti tärkeää, että opettajankoulutuksessa käsitellään tietoisesti opiskelijoiden omia kokemuksia ja että narratiivinen näkökulma on löytänyt tiensä opettajankoulutukseen. Huomion kiinnittäminen yksilön omiin kokemuksiin ja sisäisiin proses- 
seihin ei ehkä kuitenkaan riitä. Opettajan on ymmärrettävä myös hänen ulkopuolellaan tapahtuvia prosesseja. Aivan kuten kirjoittajat toteavat: ihmistä ympäröivä yhteiskunta, kulttuuri ja elämäntapa vaikuttavat identiteetin muodostumiseen.

Opettajankuvien toiseksi viimeinen artikkeli on Musiikki opettajan elämässä. Sen kirjoittajia Eeva-Kaisa Hyryä ja Leena Hyvöstä kiinnostaa se, mitä eri ikäiset opettajat kertovat suhteestaan musiikkiin, musiikin oppimiseen ja musiikinopetukseen. Artikkeli tuo esille opettajien kokemuksia musiikin opiskelusta ja musiikin roolista osana koulutyötä. Se on samalla lyhyt katsaus suomalaisen musiikinopetuksen historiaan. Hyry ja Hyvönen päätyvät näkemykseen, että useimmille opettajille musiikki on ollut elämää tukeva voimavara.

Opettajankuvassaan Kutsumus Eila Estolan ja Leena Syrjälän tavoitteena on aineistonsa pohjalta luoda katsaus siihen, mitä kutsumus on, miten se syntyy ja mitä se merkitsee opettajan työssä. Aihe on kiinnostava, sillä onhan opettajan työtä pidetty perinteisesti juuri kutsumustyönä. Kirjoittavat nostavat esille mielenkiintoisia seikkoja. He päätyvät näkemykseen, että useimmille opettajille kutsumus kehittyy työssä. Käytännön työssä opettaja alkaa vähitellen tuntea opettajantyön omakseen eli työ kutsuu. Kutsumusopettaja näkee työnsä palvelutehtävänä, saa työstään henkilökohtaista tyydytystä ja löytää persoonallisen tapansa olla opettaja. Kutsumukseen yhdistyy kokemus työn merkityksestä. Kirjoitus onnistuu arkipäiväistämään kutsumuksen myytin. Kutsu- muksessa on kyse sitoutumisesta työhön.

Lukumatkani jatkuu kirjan toiseen osaan, jolle on annettu otsikko Tarinat ja opettajaksi tulemisen taito. Tämä on lukumatkan hämmentävin osa. Johdannossa sen tarkoitukseksi mainitaan esitellä narratiivisia sovelluksia. Keskeisinä asioina ovatkin portfolio ja portfolion käyttö opettajankoulutuksen välineenä. Hämmentävää on se, että Heikkinen ei kolmessa artikkelissaan kytke kunnolla näkemyksiään aikaisempaan narratiivisuudesta käytyyn keskusteluun. Sen sijaan hän kirjoittaa kuin tavoitteena olisi osoittaa oma kekseliäisyys. Narratiivisuuden ja narratiivisen identiteetin käsitteillä on pitkät perinteet, vaikka eri tieteenaloilla niille annetaankin erilaisia tulkintoja. Omakohtaisten ajatusten ja kokemusten prosessoinnin raportointi tuntuu lukijasta liian kevyeltä lähtökohdalta, kun aiheena on narratiivisuus opettajankoulutuksen välineenä.

Jatkan kirjan toisesta osasta kolmanteen. Oikeastaan vasta sen tehtäväksi toimittajat määritelevät narratiivisuuden teoreettisten ja filosofisten lähtökohtien esittelyn. On siis mahdollista, että narratiivisuuden taustojen vähäinen käsittely kirjan toisessa osassa on tietoinen ratkaisu. Ehkä kirjan hajanaisuutta kuitenkin lievittäisi se, että toinen ja kolmas osa olisivat toisinpäin. Lisäksi kolmannen osan alkuun sijoitetut Leenan ja Hannun tarinat toimisivat hyvin kirjan johdannossa. Hannu L.T. Heikkinen ja Rauno Huttunen käsittelevät artikkelissaan Tulla siksi mitä olen ihmiskäsityksiä, identiteettiä sekä Ricouerin mimesis-käsitettä.
Tavoitteena on esitellä erilaisia näkemyksiä näistä teemoista, ja sen tehtävän artikkeli täyttää hyvin. Samalla lukijalle käy selväksi, että teoksen kirjoittajien teoreettiset lähtökohdat voivat poiketa toisistaan. Heikkinen ja Huttunen sijoittavat narratiivisen identiteetin idean kulturalismin ja eksistentialismin risteyskohtaan. Heidän mukaansa teoksen artikkeleiden kirjoittajat ovat kulturalisteja, mutta eksistentialismin ja essentialismin suhteen kirjoittajien käsitykset poikkeavat toisistaan. Toiset etsivät tosi minää ja toiset katsovat minän syntyvän kertomusten kautta. Artikkelin identiteettiä käsittelevä osuus jää kuitenkin hämäräksi. Miten sen kirjoittajat oikeasti suhteuttavat toisiinsa postmodernin identiteetin, narratiivisen minän, lohdullisen minätarinan, tosi minän tai toisessa jaksossa esille nostetun autenttisuuden käsitteen?

Kirjan viimeinen artikkeli käsittelee narratiivisuuden käsitettä. Heikkinen lähestyy sitä neljästä näkökulmasta eli narratiivisuus tiedon rakentamisena, tutkimusaineistona, analyysitapana ja ammatillisena työvälineenä. Artikkeli on narratiivisuuden lyhyt oppimäärä. Toivottavasti artikkelikokoelma kokonaisuudessaankin herättää keskustelua opettajuudesta ja etenkin narratiivisuudesta, jonka teoreettisia lähtökohtia ja mahdollisuuksia on syytä tarkastella ja tarkentaa edelleenkin. Lukumatkani lopuksi toistan ajatuksen, että Minussa elää monta tarinaa on teos, joka avaa uudenlaisen näkökulman opettajuuteen. Se tarjoaa mietittävää ja näkökulmia sekä opettajille että alan tutkijoille.

\section{Eija Kauppinen}

